\title{
Microbe assisted phytoremediation of oil sludge and role of amendments: a mesocosm study
}

\author{
S. Nanekar $\cdot$ M. Dhote $\cdot$ S. Kashyap $\cdot$ \\ S. K. Singh · A. A. Juwarkar
}

Received: 29 November 2012/Revised: 15 May 2013/Accepted: 15 October 2013/Published online: 30 October 2013

(C) Islamic Azad University (IAU) 2013

\begin{abstract}
A mesocosm study was evaluated to elucidate the influence of amendments such as microbial consortium, plant (Vetiveria zizanioides), bulking agent (wheat husk) and nutrients on remediation of oil sludge over a period of 90 days. The experiment was conducted in a $15 \mathrm{~m}^{2}$ plot which was divided into eight units comprising of soil sludge mixture (1:1) at CSIR-NEERI premises. During the experiment, oil degradation was estimated gravimetrically and polyaromatic hydrocarbons (PAHs) were quantified on GC-MS. Additionally, dehydrogenase activity was also monitored. The treatment integrated with bulking agent, nutrients, consortium and plant resulted in 28-fold increased dehydrogenase activity and complete mineralization of higher PAHs. Furthermore, $72.8 \%$ total petroleum hydrocarbons (TPH) degradation was observed in bulked treatment with plant, nutrients and consortium followed by 69.6 and $65.4 \%$ in bioaugmented treatments with and without nutrients, respectively, as compared to control $(33.4 \%)$. A lysimeter study was also conducted simultaneously using Vetiver and consortium to monitor groundwater contamination by heavy metals in oil sludge which showed a marked decrease in the concentrations of metals such as lead and cadmium in leachates. This study validates a holistic approach for remediation of oil sludge contaminated soils/sites which is a burning issue since decades by the use of microbe assisted phytoremediation technology which not only solves the problem of oil contamination but also takes care of heavy metal contamination.
\end{abstract}

S. Nanekar $(\bowtie) \cdot$ M. Dhote $\cdot$ S. Kashyap .

S. K. Singh - A. A. Juwarkar

CSIR-National Environmental Engineering Research Institute

(CSIR-NEERI), Nehru Marg, Nagpur 440020, India

e-mail: sneha.nanekar@gmail.com
Keywords Total petroleum hydrocarbons (TPH) .

Amendments - Polycyclic aromatic hydrocarbons (PAH) .

Remediation $\cdot$ Oil sludge $\cdot$ Heavy metals

\section{Introduction}

The ever increasing reliance of humans on oil and petrochemicals has increased during the past few decades. Oil sludge contamination occurs predominately during different processes such as transport, storage, drilling, etc. Oil sludge is a complex mixture of alkanes, aromatic hydrocarbons, NSO (nitrogen-sulfur-oxygen containing compounds) and asphaltene fractions (Beskoski et al. 2011). Due to the structural complexity and low bioavailability of these compounds, their natural degradation in the environment is negligible. Among these, polycyclic aromatic hydrocarbons (PAHs) are difficult to degrade as they are highly recalcitrant in nature and persist in the environment due to their hydrophobicity. The association of PAHs with co-pollutants such as other hydrocarbons and heavy metals is another factor that can prolong their residence time in the environment. It has long been known that PAHs can have serious deleterious effects on human health, and toxic effects of PAHs continue as they display acute carcinogenic, mutagenic and teratogenic properties (Bamforth and Singleton 2005). The biodegradability of oil components in the decreasing order can be shown as: $n$-alkanes $>$ branchedchain alkanes $>$ branched alkenes $>$ low molecular weight $n$-alkyl aromatics $>$ monoaromatics $>$ cyclic alkanes $>$ PAHs $>$ asphaltenes (Tyagi et al. 2011). Remediation of oil sludge due to these visible hazards has gained a substance. There are many physico-chemical methods for remediation of oil sludge (i.e., thermal treatment, dig and dump method, chemical method, separation techniques and stabilization/ 
solidification technology), but those are expensive and have their own disadvantages for they not being environmental friendly and lead to destruction of soil fertility. To overcome the limitations of these physico-chemical technologies, bioremediation can prove to be an effective and eco-friendly technology which makes use of either indigenous bacteria or introduces exogenous bacterial cultures capable of degrading the contaminant. It has many advantages over physicochemical methods for it being eco-friendly, safe, gives complete mineralization of pollutant which in turn conserves soil texture and characteristics and is also costeffective (Salleh et al. 2003; Abdulsalam et al. 2011). Many microbial strains are capable of degrading specific hydrocarbon compounds. A single bacterial species has only limited capacity to degrade all the fractions of hydrocarbons present in oil sludge since it is a complex mixture of different compounds as mentioned above. Hence, a mixture of bacterial armies that can degrade a broad range of the hydrocarbon constituents of the oil sludge should be employed. The remediation process can be accelerated by adding the indigenous bacteria isolated from site that are already adapted in the contaminated environment (Jain et al. 2010). Environmental factors such as soil type and structure; $\mathrm{pH}$; temperature; and the presence of adequate levels of oxygen, nutrients and water for the activity of the pollutant-degrading microbial community should be kept in mind while remediating a contaminated site (Bamforth and Singleton. 2005). Thus, addition of microbial consortium at the site of contamination is an effective method for remediation of oily sludge (Vasudevan and Rajaram 2001; Mishra et al. 2001). Furthermore, use of plant species for remediation of oil sludge can also tackle the heavy metal contamination since certain plant species are known to accumulate metals in either roots or shoots (Juwarkar et al. 2010). Besides, degradation of hydrocarbons in oil sludge is enhanced by the use of bulking agents and inorganic nutrients (Vasudevan and Rajaram 2001). Hence, to deal with all possible problems created by oil sludge contamination including both heavy metal and hydrocarbon contamination, the collective use of plants, microbes, bulking agent and nutrients is suggested. The aim of this study is to monitor the combined output of all the above-mentioned amendments, resulting in a microbe assisted phytoremediation technology (MAPT) for remediation of oil sludge under natural environmental conditions. To achieve this goal, a 90 days mesocosm study was initiated at CSIR-NEERI premises in the month of December, 2011. MAPT is an onsite remediation technology unlike other physico-chemical techniques which transfer the contaminant to other place for remediation, thereby increasing the cost of transportation. Also, it is a low-input approach for remediation in which one time bioaugmentation and plantation are the only interventions. Vetiver plant used can serve as a resource to perfume industry as it is used for extraction of aromatic oils. Moreover, the bulking agent added is an inexpensive agricultural waste that is easily available in bulk quantities. Thus, MAPT will prove to be cost-effective, eco-friendly, deal with heavy metals problem that is also a component of oil sludge and help to overcome the environmental hazard of oil sludge contamination.

\section{Materials and methods}

Site preparation and experimental set up

The study was performed in a randomized block design (RBD), and eight units were filled with $50 \%$ oil sludge contaminated soil to form about $20 \mathrm{~cm}$ surface layer. The tank bottom oil sludge used for the experiment was collected from Gujarat oil refinery, Vadodara, India. The plant used for the study was Vetiveria zizanioides due to its properties such as dense and massive root system, high biomass production, rapid growth rate, high tolerance and adaptability to a wide range of climatic and environmental conditions, ability to accumulate heavy metals and tolerance to petroleum hydrocarbon toxicity (Danh et al. 2009). $V$. zizanioides saplings (15 days old) of same the height $(30 \mathrm{~cm})$ were purchased from Shri Shell nursery, Nagpur. Bulking agent $4 \%$ (wt./wt.) was mixed in the respective treatments, and the plots were acclimatized for 7 days. The bulking agent was ground and sieved through 2-mm mesh. The characteristics of bulking agent were total $\mathrm{N}-0.51 \%$, total $\mathrm{P}-0.030 \%$ and total $\mathrm{K}-0.95 \%$. Total nitrogen was estimated by standard Kjeldahl method, and total potassium and phosphorus were estimated according to methods reported by Jackson (1973).

Different treatments are mentioned in Table 1. Inorganic supplementation of nitrogen was done by adding commercially available urea-based fertilizer to maintain the $\mathrm{C} / \mathrm{N}$ ratio of 100:10. Also the moisture content of soil

Table 1 Treatments of mesocosm study

\begin{tabular}{lllll}
\hline Treatments & \multicolumn{2}{l}{ Amendments } & & \\
\cline { 2 - 5 } & $\begin{array}{l}\text { Microbial } \\
\text { Consortium }\end{array}$ & Nutrients & $\begin{array}{l}\text { Bulking agent } \\
\text { (wheat husk) }\end{array}$ & $\begin{array}{l}\text { Plant } \\
\text { (Vetiveria } \\
\text { zizanioides) }\end{array}$ \\
\hline Control [a] & - & - & - & - \\
Control [b] & - & + & - & - \\
T1 [a] & + & - & - & - \\
T1 [b] & + & + & - & - \\
T2 [a] & - & - & - & + \\
T2 [b] & - & + & - & + \\
T3 [a] & + & - & + & + \\
T3 [b] & + & + & + & + \\
\hline
\end{tabular}


was maintained between 60 and $70 \%$. Aeration was provided by manual plowing, thrice every month, to provide increased interaction of microorganisms with the contaminant and amended nutrients.

Microbial consortium, approximately $10^{9} \mathrm{CFU} / \mathrm{g}$ soil, was mixed directly with soil without any carrier material. Composite sampling of surface soil $(20 \mathrm{~cm})$ was carried out at an interval of 30 days during the course of experiment. The samples were homogenized, sieved through 2-mm mesh and preserved at $4{ }^{\circ} \mathrm{C}$ until further analysis.

Preparation of microbial consortium

The consortium was formed with organisms isolated from oil-sludge-contaminated site through enrichment studies using modified minimal salts medium (MSM) adopted from Verma et al. (2006) with additionally supplemented vitamin solution, $1 \mathrm{ml} / \mathrm{L}$ (HiMedia). Oil sludge was used as sole carbon and energy source. After several enrichment cycles, $0.1 \mathrm{ml}$ from appropriate dilution was spread on MSM agar plates with crude oil as carbon source. The bacterial strains were identified through biochemical tests and 16S-rRNA sequencing. The consortium was formed of four hydrocarbon-degrading organisms, identified as Bacillus subtilis, Bacillus pumilis, Pseudomonas aeruginosa and Pseudomonas azotoformans. These cultures were then grown till mid-log phase individually in MSM and mixed in equal proportions to form a consortium. The cells were concentrated by centrifuging the broth at $8,000 \mathrm{rpm}$ for $10 \mathrm{~min}$ and the pellet was dissolved in autoclaved distilled water, and this consortium was then mixed with the contaminated soil in respective treatments.

\section{Initial characterization oil sludge and soil}

Oil sludge was characterized for oil content, total petroleum hydrocarbons (TPH) and its fractions, ash and moisture content. Ash and moisture content were determined by ASTM D 2974 (2000) method. The soil was characterized for parameters such as organic carbon, organic matter, total nitrogen and total microbial count. Nitrogen content of soil was determined using the Kjeldahl method, and organic carbon and organic matter were determined by Walkley and Black method. The $\mathrm{pH}$ was determined using $\mathrm{pH}$ meter (HANNA, HI4521) on 1:2 (wt./vol.) soil/distilled water after 30-min equilibration. Total microbial count was performed by standard plate count method.

\section{Estimation of oil and TPH}

The oil content in the samples was determined by soxhlet extraction method (USEPA. Method 3540C 1996) with DCM:Acetone (1:1) as extracting solvent. The different TPH fractions [aliphatic, aromatic, NSO (nitrogen-sulfur-oxygen containing compounds) and asphaltene] were separated using method given by Mishra et al. (2001). The samples were dissolved in $30 \mathrm{ml} n$-pentane to separate insoluble asphaltene fraction from the soluble ones. The soluble fractions were laid on glass columns $(50 \times 1.5 \mathrm{~cm})$ filled with activated silica gel of mesh size 60-120. Aliphatic fractions were separated using hexane as eluting solvent; benzene was used for eluting out aromatic fractions containing PAH. Similarly, methanol was used to separate NSO fraction. Fractions were dried at room temperature in a fume hood. The degradation of TPH fractions was calculated gravimetrically in comparison with the controls that contained only a soil and sludge mixture.

\section{Quantification of PAH degradation using GC-MS}

The aromatic fractions separated by silica gel fractionation procedure were subjected to GC-MS analysis for quantification of $\mathrm{PAH}$ compounds. The dried fractions were dissolved in benzene and made up to $10 \mathrm{ml}$ before analysis. Varian 450 GC and MS 240 was used for PAH analysis. Separation was carried out using DB-5 MS column having length $30 \mathrm{~m}, 0.25 \mathrm{~mm}$ ID and $0.25 \mu$ film thickness. Injector temperature was set at $270{ }^{\circ} \mathrm{C}$. Oven temperature

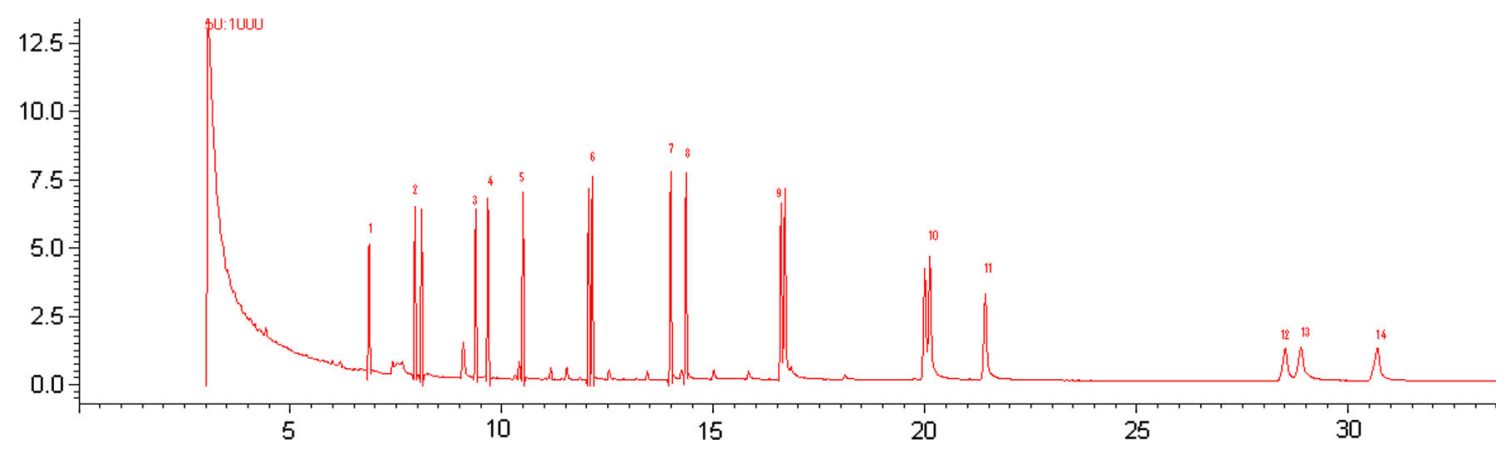

Fig. 1 Standard chromatograph for PAH compounds. 1-Naphthalene, 2-Naphthalene,1-methyl-, 3-Acenaphthylene, 4-Acenaphthene, 5-Fluorene, 6-Phenanthrene, 7-Fluoranthene, 8-Pyrene,

9-Chrysene, 10-Benzo[e] pyrene, 11-Benzo[b] fluoranthene, 12-Benzo[GHI] perylene, 13-Dibenzo[a,h] anthracene, 14Indeno[1,2,3-CD] Pyrene 
was programmed from $60{ }^{\circ} \mathrm{C}$, hold for 1 min, heated to $270{ }^{\circ} \mathrm{C}$ at rate of $15^{\circ} \mathrm{C} / \mathrm{min}$ and hold for $5 \mathrm{~min}$. Ion trap was heated to $150{ }^{\circ} \mathrm{C}$ and acquisition mass range from 50 to 1,000 dalton; $1 \mu \mathrm{l}$ sample was injected into $\mathrm{GC}$, and fragmentation pattern was observed. The 14 mix PAH standard used was from Dr. Ehrenstorfer GmbH (Augsburg, Germany) (Fig. 1).

Estimation of dehydrogenase activity

Dehydrogenase activity was estimated by 2,3,5-triphenyltetrazolium chloride (TTC) reduction method (Casida et al. 1964). The mixture of soil, $1 \%$ TTC and glucose was incubated at $37{ }^{\circ} \mathrm{C}$ for $24 \mathrm{~h}$. The triphenylformazone (TPF) formed was extracted by ethanol and read at $484 \mathrm{~nm}$ on UV-vis Spectrophotometer (Perkin Elmer, Lamda 900). One unit activity was represented as $\mu \mathrm{g} \mathrm{TPF} / \mathrm{g} / \mathrm{h}$.

Heavy metal analysis

A column lysimeter study was conducted parallel to mesocosm study to monitor the ground water pollution due to water-soluble heavy metals in oil sludge. The treatments used in lysimeter study were control (soil and oil sludge only), L1 ( $V$. zizanioides + soil + oil sludge $)$ and L2 (Microbial consortium $+V$. zizanioides + soil + oil
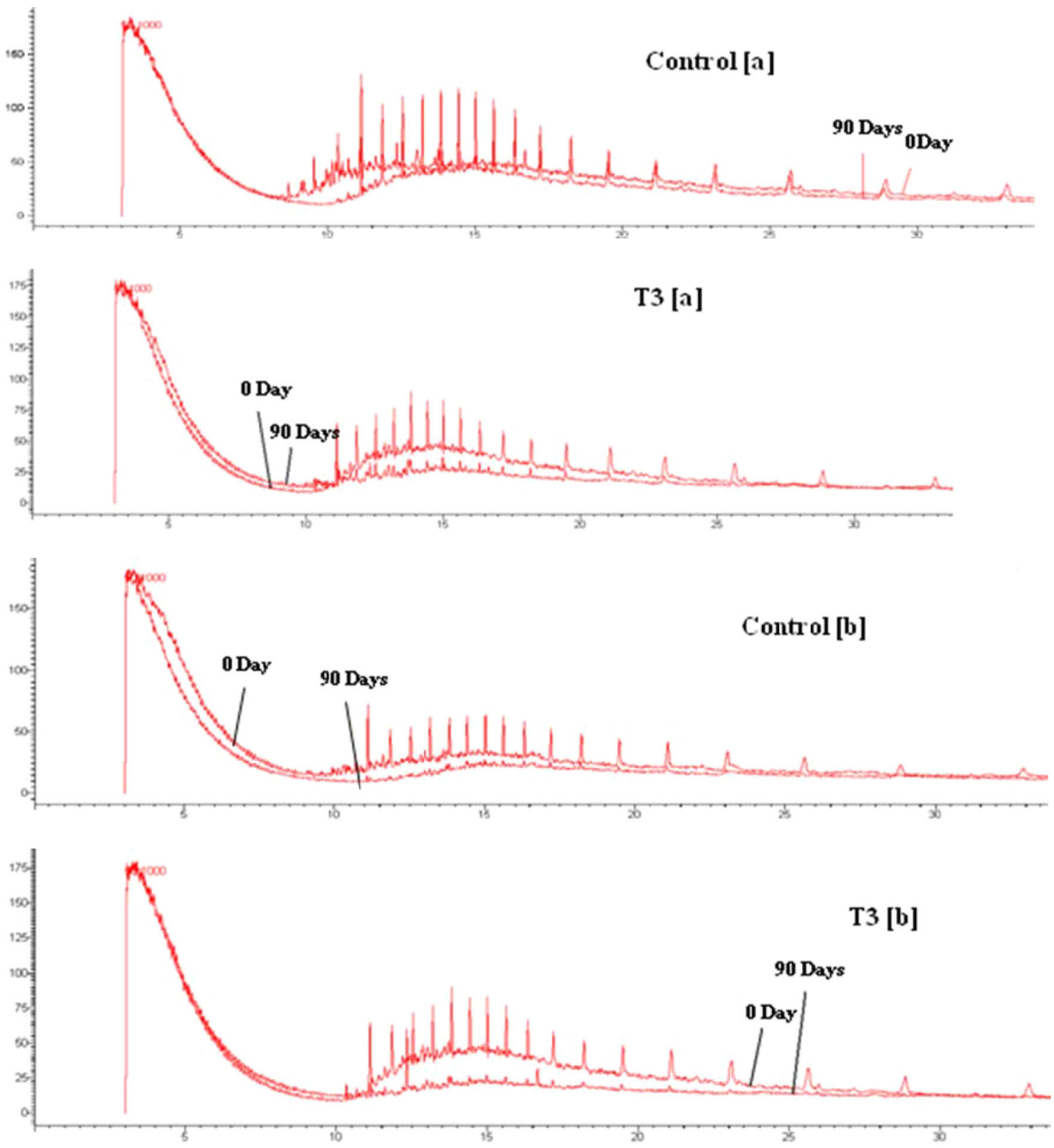

Fig. 2 Comparative GC-MS chromatographs on 0 and 90 days of control [a], control [b], Treatment T3 [a] and T3 [b] 
sludge). PVC Columns of height $1.5 \mathrm{~m}$ and diameter $15 \mathrm{~cm}$ were filled with layers of gravels, sand and soil; $5 \%$ oil sludge was laid on the top layer. A small pipe was fitted at the bottom to collect the leachate. The leachate samples after 60 days study were subjected to analysis on ICP-OES for quantification of different heavy metals. (ICP-OES Thermo Fisher ICAP 6300DUO)

\section{Data analysis}

The experiments were carried out in triplicates. The mean, standard deviation and correlation between dehydrogenase activity and percentage oil degradation (Pearson's correlation coefficient) were calculated using analysis of variance (ANOVA). The statistical significance in this analysis was defined at $p \leq 0.05$.

\section{Results and discussion}

Initial characterization of soil and oil sludge

The initial characterization of oil sludge and soil is presented in Table 2. The moisture and ash content of oil sludge were 1.6 and $22.01 \%$, respectively. Tank bottom sludge was rich in oil having $62.3 \mathrm{~g} / \mathrm{kg}$ oil content, and among TPH fractions, the lowest concentration was of NSO $(36.2 \mathrm{~g} / \mathrm{kg})$ fraction and highest was of asphaltene $(98.6 \mathrm{~g} / \mathrm{kg})$. The composition of oil and its fraction varies with source of crude (light or heavy), refining process and location of refinery. The oil sludge used in this study is an end product of mixed crude which resulted in heavy asphaltene fraction. The $\mathrm{C} / \mathrm{N}$ ratio of soil sludge mixture was estimated as 365:1 and nitrogen was supplemented to maintain optimum ratio (100:10) which was also maintained by $\mathrm{Xu}$ and $\mathrm{Lu}$ (2010). The initial bacterial count was $25 \times 10^{4}$ which implies that bioaugmentation was required for enhanced degradation, as the population of microorganisms for optimal degradation should be around $10^{5} \mathrm{CFU} / \mathrm{g}$ or more (Mittal and Singh 2010).

\section{Mesocosm studies}

\section{Control [a]}

At the end of study (90 days), no significant reduction in concentration of PAH compounds was observed (Fig. 2). However, the oil content of contaminated soil reduced by $40.64 \%$ (Fig. 3) and TPH content reduced from $222.6 \pm 0.52$ to $148.2 \pm 0.76 \mathrm{~g} / \mathrm{kg}(33.4 \%)$ Table 4 . A slight increase in dehydrogenase activity was observed which might be due to metabolic activity of native microflora as per the results in Fig. 3. The reduction in oil and TPH might be attributed to the abiotic losses such as evaporation
Table 2 Initial characterization of oil sludge and soil used for study

\begin{tabular}{ll}
\hline Constituents & Concentration \\
\hline Oil sludge & \\
Moisture $(\%)$ & 1.65 \\
Ash $(\%)$ & 22.01 \\
Oil content $(\mathrm{g} / \mathrm{kg})$ & 62.3 \\
TPH fractions & \\
Aliphatic fraction $(\mathrm{g} / \mathrm{kg})$ & 75 \\
Aromatic fraction $(\mathrm{g} / \mathrm{kg})$ & 42 \\
NSO fraction $(\mathrm{g} / \mathrm{kg})$ & 36.2 \\
Asphaltene fraction $(\mathrm{g} / \mathrm{kg})$ & 98.6 \\
Soil & \\
pH & 6.8 \\
Organic matter $(\%)$ & 1.98 \\
Organic carbon $(\%)$ & 0.9 \\
Total nitrogen $(\mathrm{mg} / \mathrm{kg})$ & 196 \\
Total bacterial count $(\mathrm{CFU} / \mathrm{g})$ & $25 \times 10^{4}$ \\
C/N (after mixing sludge and soil) & $365: 1$ \\
\hline
\end{tabular}

of low volatile fraction of oil sludge, photooxidation, etc., and some degradation by indigenous microbes present in the soil sludge mixture. Mittal and Singh (2010) have also reported losses due to volatilization and photooxidation.

\section{Control [b]: effect of biostimulation}

An eightfold increase in dehydrogenase activity was found after 90 days, and during same duration oil and TPH content reduced by $41.5 \%$ (Fig. 3; Table 4). Previous studies reveal that addition of nutrients enhances the degradation process by providing optimum growth parameters for microorganisms (Pelletier et al. 2004). However, in the present study, addition of $\mathrm{N}$ alone had a minor effect on degradation and dehydrogenase activity as compared to other soil amendments.

\section{T1 [a]: effect of bioaugmentation}

The amendment of microbial consortium proved efficient in depleting $65 \%$ of TPH $(235 \pm 0.81$ to $82 \pm 0.76 \mathrm{~g} / \mathrm{kg})$ and $65.8 \%$ of oil from the contaminated soil with increased enzyme activity from $71.36 \pm 1$ to $682.06 \pm$ $0.5 \mu \mathrm{g}$ TPF/g/h after 90 days (Table 4; Fig. 3). The bioaugmentation also resulted in complete removal of higher weight PAH and dibenzo $(\mathrm{a}, \mathrm{h})$ anthracene. A comparative higher activity and degradation rates in this treatment can be attributed to the consortium augmented at the beginning of the study which adapted to oil and its components for functional growth. Additionally, the induced catabolic system of microbes on exposure to toxic organic compounds improves the degradation rate. 
Table 3 Heavy metal content in different treatments after 60 days

\begin{tabular}{|c|c|c|c|c|c|c|}
\hline \multirow[t]{2}{*}{ Heavy metal } & \multicolumn{3}{|l|}{0 Day } & \multicolumn{3}{|l|}{60 Days } \\
\hline & Control & L1 & L2 & Control & L1 & L2 \\
\hline $\mathrm{Zn}$ & 0.026 & 0.089 & 0.0155 & 0.021 & 0.088 & 0.0055 \\
\hline $\mathrm{Pb}$ & 0.02775 & 0.02465 & 0.0235 & 0.02705 & 0.0211 & 0.01915 \\
\hline $\mathrm{Cd}$ & 0.02035 & 0.01225 & 0.01745 & 0.01925 & 0.01095 & 0.01085 \\
\hline $\mathrm{Ni}$ & 0.0985 & 0.089 & 0.0855 & 0.097 & 0.08 & 0.0835 \\
\hline $\mathrm{Mn}$ & 0.0365 & 0.039 & 0.0385 & 0.0335 & 0.036 & 0.036 \\
\hline $\mathrm{Fe}$ & 0.003 & 0.008 & 0.014 & 0.02 & 0.0075 & 0.011 \\
\hline $\mathrm{Cr}$ & 0.032 & 0.053 & 0.0555 & 0.0315 & 0.046 & 0.04 \\
\hline
\end{tabular}
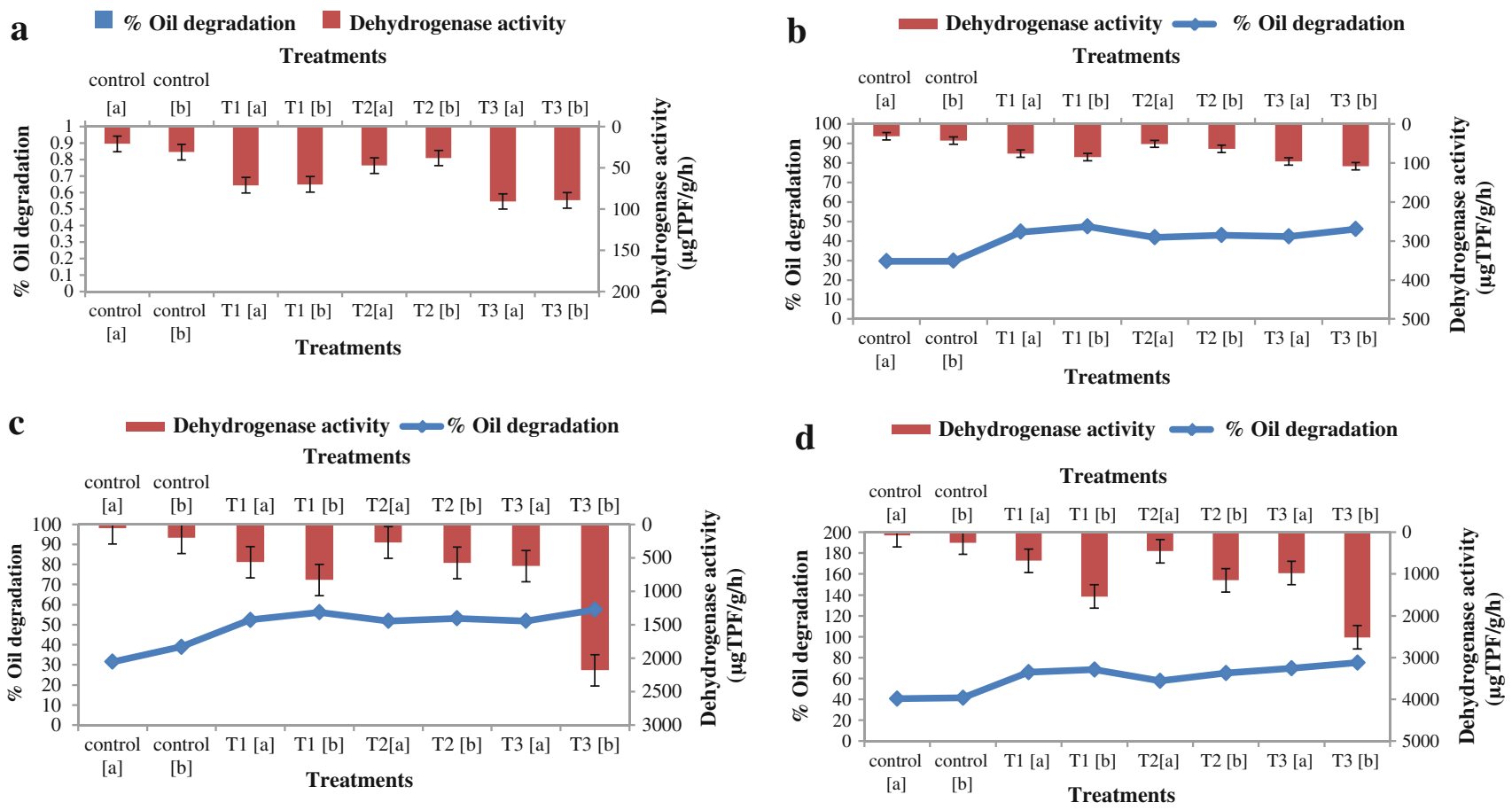

Fig. 3 Dehydrogenase activity and percent oil degradation during 90 days. a 0 day profile, b 30 days profile, c 60 days profile, d 90 days profile

\section{T1 [b]: effect of bioaugmentation and biostimulation}

The combined effect of biostimulation and bioaugmentation of contaminated soil resulted in $69.5 \%$ reduction in TPH $(230.3 \pm 0.65$ to $70 \pm 0.81 \mathrm{~g} / \mathrm{kg})$ along with $68.5 \%$ oil removal (Table 4; Fig. 3). There was a sudden increase in dehydrogenase activity after 30 days $(84.6 \pm 0.5 \mu \mathrm{g}$ TPF/ $\mathrm{g} / \mathrm{h}$ ) which almost doubled at the end of the study as compared to 60 day $(830.2 \pm 0.7$ to $1536.5 \pm 0.5 \mu \mathrm{g} \mathrm{TPF} / \mathrm{g} / \mathrm{h})$ (Fig. 3). Microorganisms are known to produce dehydrogenase enzymes that catalyze the degradation process by oxidizing hydrocarbons. During this process, the double bond of carbon is broken and the adjacent hydrogen atom is transferred to hydrogen receptor (Li et al. 2002). The degradation of oil was more rapid during the first 30 days
(47.4\%) which increased gradually till 90 days $(68.5 \%)$. This shows that microorganisms have acclimatized to the contamination and are utilizing oil sludge as a carbon source for growth. As a result, by using oil sludge as carbon source, the microorganisms might have increased in number showing corresponding increase in dehydrogenase activity. Similar kind of results were observed by Zhang et al. (2009) where they observed increase in dehydrogenase activity in unplanted petroleum contaminated soil till 150 days. The GC-MS profile shown in Table 5 confirms $100 \%$ degradation of acenaphthene and dibenzo $(\mathrm{a}, \mathrm{h})$ anthracene. Maintaining $\mathrm{C} / \mathrm{N}$ ratio to the requirement of microbes proved beneficial in degradation as it enhanced the process by increasing the microbial activity, and also bioaugmentation proved beneficial in depleting oil and TPH content. 
Table 4 Total petroleum hydrocarbon degradation in different treatments

\begin{tabular}{|c|c|c|c|c|}
\hline \multirow[t]{2}{*}{ Treatments } & \multicolumn{4}{|c|}{ Total petroleum hydrocarbons (TPH) } \\
\hline & $\begin{array}{l}\text { Incubation } \\
\text { period (days) }\end{array}$ & $\begin{array}{l}\text { Initial concentration } \\
(\mathrm{g} / \mathrm{kg})\end{array}$ & $\begin{array}{l}\text { Final concentration } \\
(\mathrm{g} / \mathrm{kg})\end{array}$ & $\begin{array}{l}\text { Degradation } \\
(\%)\end{array}$ \\
\hline \multirow[t]{3}{*}{ Control [a] } & 30 & $222.6 \pm 0.52^{\mathrm{a}}$ & $196.9 \pm 1^{\mathrm{a}}$ & 11.5 \\
\hline & 60 & $222.6 \pm 0.52^{\mathrm{a}}$ & $173.2 \pm 1.7^{\mathrm{a}}$ & 22.2 \\
\hline & 90 & $222.6 \pm 0.52^{\mathrm{a}}$ & $148.2 \pm 0.76^{\mathrm{a}}$ & 33.4 \\
\hline \multirow[t]{3}{*}{ Control [b] } & 30 & $254.8 \pm 0.91^{\mathrm{a}}$ & $230.2 \pm 0.87^{\mathrm{a}}$ & 9.7 \\
\hline & 60 & $254.8 \pm 0.91^{\mathrm{a}}$ & $180.4 \pm 0.77^{\mathrm{a}}$ & 29.1 \\
\hline & 90 & $254.8 \pm 0.91^{\mathrm{a}}$ & $151.6 \pm 0.4^{\mathrm{a}}$ & 40.5 \\
\hline \multirow[t]{3}{*}{$\mathrm{T} 1$ [a] } & 30 & $234.4 \pm 0.81^{\mathrm{a}}$ & $201.2 \pm 0.65^{\mathrm{a}}$ & 14.2 \\
\hline & 60 & $234.4 \pm 0.81^{\mathrm{a}}$ & $135.7 \pm 0.55^{\mathrm{a}}$ & 42.1 \\
\hline & 90 & $234.4 \pm 0.81^{\mathrm{a}}$ & $81.3 \pm 0.76^{\mathrm{a}}$ & 65.4 \\
\hline \multirow[t]{3}{*}{$\mathrm{T} 1[\mathrm{~b}]$} & 30 & $231 \pm 0.65^{\mathrm{a}}$ & $180.7 \pm 0.43^{\mathrm{a}}$ & 21.7 \\
\hline & 60 & $231 \pm 0.65^{\mathrm{a}}$ & $110.3 \pm 0.98^{\mathrm{a}}$ & 52.3 \\
\hline & 90 & $231 \pm 0.65^{\mathrm{a}}$ & $70.2 \pm 0.87^{\mathrm{a}}$ & 69.6 \\
\hline \multirow[t]{3}{*}{$\mathrm{T} 2[\mathrm{a}]$} & 30 & $267.4 \pm 0.60^{\mathrm{a}}$ & $210.9 \pm 0.45^{\mathrm{a}}$ & 21.1 \\
\hline & 60 & $267.4 \pm 0.60^{\mathrm{a}}$ & $161.2 \pm 0.47^{\mathrm{a}}$ & 39.7 \\
\hline & 90 & $267.4 \pm 0.60^{\mathrm{a}}$ & $120.1 \pm 0.80^{\mathrm{a}}$ & 55.1 \\
\hline \multirow[t]{3}{*}{$\mathrm{T} 2[\mathrm{~b}]$} & 30 & $260.3 \pm 0.75^{\mathrm{a}}$ & $230.8 \pm 0.65^{\mathrm{a}}$ & 11.3 \\
\hline & 60 & $260.3 \pm 0.75^{\mathrm{a}}$ & $155.9 \pm 0.90^{\mathrm{a}}$ & 40.1 \\
\hline & 90 & $260.3 \pm 0.75^{\mathrm{a}}$ & $102.3 \pm 1.04^{\mathrm{a}}$ & 60.7 \\
\hline \multirow[t]{3}{*}{$\mathrm{T} 3$ [a] } & 30 & $249.5 \pm 0.95^{\mathrm{a}}$ & $191.6 \pm 0.75^{\mathrm{a}}$ & 23.2 \\
\hline & 60 & $249.5 \pm 0.95^{\mathrm{a}}$ & $138.2 \pm 0.7^{\mathrm{a}}$ & 44.6 \\
\hline & 90 & $249.5 \pm 0.95^{\mathrm{a}}$ & $77.6 \pm 0.55^{\mathrm{a}}$ & 68.9 \\
\hline \multirow[t]{3}{*}{$\mathrm{T} 3[\mathrm{~b}]$} & 30 & $227.4 \pm 0.92^{\mathrm{a}}$ & $185.4 \pm 0.52^{\mathrm{a}}$ & 18.4 \\
\hline & 60 & $227.4 \pm 0.92^{\mathrm{a}}$ & $110.9 \pm 0.35^{\mathrm{a}}$ & 51.2 \\
\hline & 90 & $227.4 \pm 0.92^{\mathrm{a}}$ & $61.8 \pm 0.56^{\mathrm{a}}$ & 72.8 \\
\hline
\end{tabular}

content. Results are depicted in Table 4 and Fig. 3. The GCMS results showed that after completion of the experiment, PAHs such as naphthalene, 1-methyl, acenaphthylene, acenaphthene, fluorene, phenanthrene, fluoranthene, pyrene and chrysene were found with reduced concentrations. Out of the above-mentioned 8 PAH compounds, naphthalene, 1-methyl was degraded from 214 to $42 \mathrm{ppm}$, acenaphthene from 356 to $245 \mathrm{ppm}$ and fluorine from 850 to $762 \mathrm{ppm}$ showed maximum reduction after 90 days (Table 5). The overall TPH degradation was better as compared to that of with only plant. Dehydrogenase activity increased 29 times from $38.3 \pm 0.7$ to $1148.17 \pm 0.7 \mu \mathrm{g}$ TPF/g/h (Fig. 3). Brandt et al. (2006) has mentioned in his study that petroleum hydrocarbons have high carbon content but poor nitrogen and phosphorus content, and microbes use up the available nutrients during mineralization of hydrocarbons. Hence, supplementation of nutrients helps in increasing the degradation rate.

\section{T3 [a]: effect of bioaugmentation, phytoremediation and bulking agent}

This treatment had an additional advantage of bulking agent to increase the porosity of soil. The outcome of this dation of TPH compounds from $260.3 \pm 0.75$ to $102.3 \pm 1.04 \mathrm{~g} / \mathrm{kg}(60.7 \%)$ and nearly $65 \%$ reduction in oil 


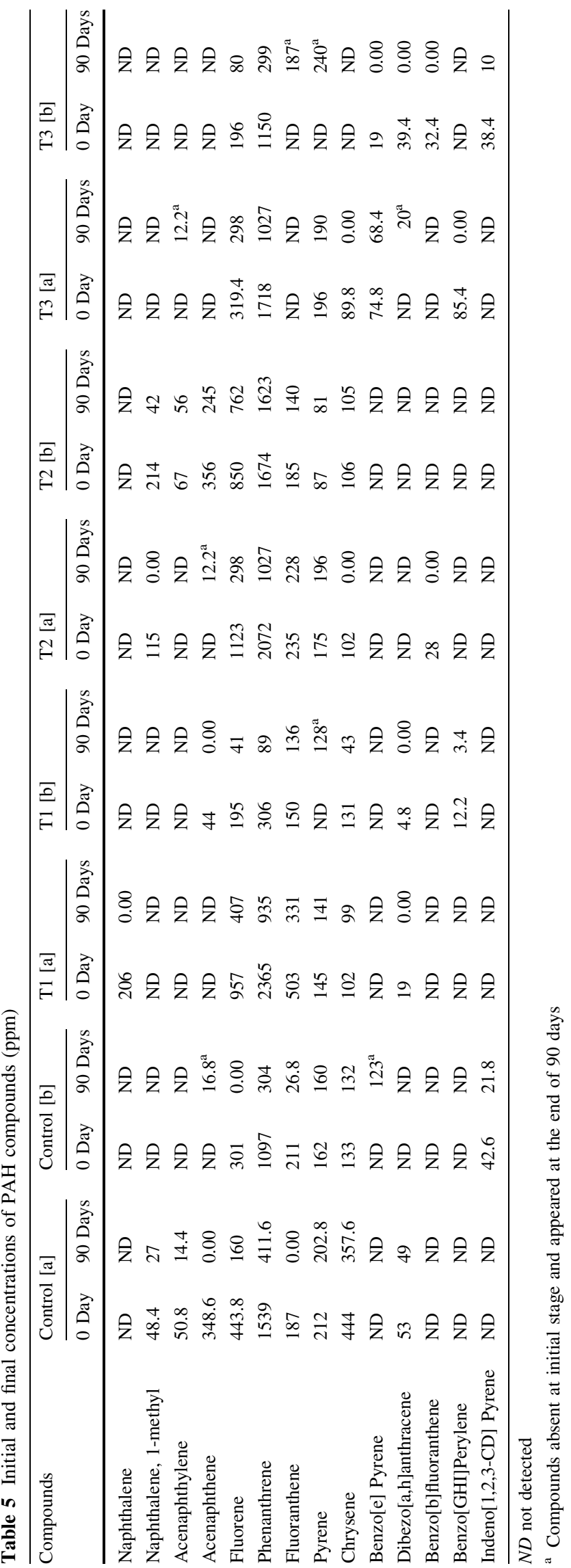

addition was degradation of oil and TPH, 69.6 and $68.9 \%$, respectively (Fig. 3; Table 4). Though this treatment was effective as compared to other treatments discussed above in degrading oil, but treatment $\mathrm{T} 1[\mathrm{a}]$ and $\mathrm{T} 1[\mathrm{~b}]$ showed much better TPH degradation. This might be attributed to competition for nutrients between rhizospheric bacteria and added consortium. Dehydrogenase activity increased from $90.96 \pm 1.05$ to $975.2 \pm 1.1 \mu \mathrm{g} \mathrm{TPF} / \mathrm{g} / \mathrm{h}$ (Fig. 3). Benzo[GHI]Perylene and chrysene were degraded completely (Table 5). Addition of bulking agent reduces remediation time for oil-contaminated soil by reducing the oil-saturated aggregates and thus making them available for microbial degradation (Rhykerd et al. 1999). The addition of bulking agent might be reason for enhanced dehydrogenase activity, TPH and oil degradation as compared to control. Also bulking agent addition increases porosity of soil providing aeration favouring microbial growth.

\section{T3 [b]: effect of bioaugmentation, biostimulation, phytoremediation and bulking agent}

This treatment was the best among all the other treatments. Maximum reduction in oil and TPH content was observed after 90 days. TPH content reduced from $228 \pm 0.9$ to $62 \pm 0.5 \mathrm{~g} / \mathrm{kg}$, i.e., $72.8 \%$ (Table 4). Also, oil was degraded up to $75.02 \%$ (Fig. 3). The reduced TPH degradation shown by treatment $\mathrm{T} 3[\mathrm{~b}]$ as compared to treatments $\mathrm{T} 1$ [a] and $\mathrm{T} 1$ [b] seems to be handled by the addition of nutrients, bulking agent and Vetiver in this treatment resulting in maximum TPH degradation. Dehydrogenase activity increased 28 folds after 90 days (Fig. 3). Maximum degradation can be justified by complete mineralization of three higher PAH compounds, benzo[e] pyrene, dibezo[a,h] anthracene and benzo[b] fluoranthene. The concentration of indeno [1,2,3-CD] pyrene is reduced from 38.4 to $10 \mathrm{ppm}$ and that of phenanthrene from 1,150 to $299 \mathrm{ppm}$ (Table 5). Oil degradation by using microbial consortium and nutrient amendments have been reported by Alvarez et al. (2011) with positive results. Also Chang and Richard (1998) have reported enhanced oil remediation by addition of bulking agent. Brandt et al. (2006) during their research carried out on phytoremediation of petroleum contamination found that Vetiver was efficient in degrading the contaminant. This study resulted in degradation of oil and TPH compounds by using all possible technologies implemented till date by making use of plant (phytoremediation), microbial consortium (bioremediation), addition of bulking agent and nutrient (biostimulation) together, and hence has proved its efficiency over conventional remediation technologies.

A common observation in some of the treatments was that along with degradation of higher-ring compounds there was increase in the concentration of lower molecular weight compounds. This increase in concentration of 
lower-ring compounds may be due to conversion of one form into another as a drop in metabolism process. Similar types of results were observed by Edema et al. (2011). The results are depicted in Table 5. GC-MS chromatographs for treatments T3 [a], T3 [b], control [a] and control [b] are depicted in Fig. 2.

\section{Dehydrogenase activity versus oil degradation}

Dehydrogenase is an oxidoreductase enzyme present only in viable cells and is considered as a biomarker for changes in microbial activity due to changes in soil management and climatic conditions (Roldan et al. 2004). In the present study, a gradual increase in dehydrogenase activity was observed with incubation time till the end of study. Additionally, bioaugmented treatments ( $\mathrm{T} 1$ and $\mathrm{T} 3$ ) resulted in $20 \%$ higher activity as compared to control. At the same time, biostimulation of treatments also showed an enhanced activity as compared to non-stimulated counterparts. The increase in activity was more in $\mathrm{T} 3[\mathrm{~b}]$ treatment as compared to biostimulation and bioaugmentation alone. This can be justified by all favorable conditions provided for growth of hydrocarbon degraders, i.e., addition of consortium, root exudates by Vetiver, nutrients for stimulation of augmented and indigenous bacteria and proper aeration by bulking agent addition. Oil degradation rate during 30 days was higher as compared to 60 and 90 days. This might be due to the reason that lower and easily available hydrocarbons are preferred to degradation and the rest higher-ring compounds are left to degrade at the end. Similar results were observed with oil degradation rates as in dehydrogenase activity in which $\mathrm{T} 3[\mathrm{~b}]$ proved most efficient in degradation. The end results of study show that a strong positive correlation was found between dehydrogenase activity and percent oil degradation with Pearson's correlation coefficient $R=0.89$ which was significant at $p \leq 0.05$. This correlation infers that increase in dehydrogenase activity can be used to estimate oil degradation rates.

\section{Heavy metal analysis}

The treatments L1 and L2 showed reduced concentrations of lead $(\mathrm{Pb})$ and cadmium $(\mathrm{Cd})$ after 60 days. In L1 treatment, $\mathrm{Pb}$ concentration reduced from 0.0246 to $0.0211 \mathrm{ppm}$ and that of $\mathrm{Cd}$ from 0.01225 to $0.01095 \mathrm{ppm}$ (Table 3).The concentrations of $\mathrm{Pb}(0.0235-0.01915 \mathrm{ppm})$ and $\mathrm{Cd}(0.01745-0.01085 \mathrm{ppm})$ were also found to reduce in treatment L2. During this study, a reduction in the concentration of all metals was observed but it was more prominent in case of $\mathrm{Pb}$ and $\mathrm{Cd}$. The reduction in concentration of other metals in the treatments L1 and L2 was found to be negligible. Some metals in soil are not bioavailable as they are in soil precipitate form and/or embedded in structure of silicate minerals in the soil (Lasat 2000). Hence, the plant might not have been able to uptake other metals, resulting in negligible reduction in concentration of these metals in the leachates. In a phytoremediation study, Danh et al. (2009) mentioned that $\mathrm{Cd}$ is accumulated in the shoots of Vetiver plant while $\mathrm{Pb}$ is accumulated both in shoots as well as roots. Hooda (2007) also reported that rhizospheric bacteria facilitate the uptake of heavy metals by phytoextraction/phytosequestration mechanism. On the other side, the reduction in metal concentration may be contributed by adsorption of metals on bacterial cell wall. The structural polymers in bacterial cell wall provide acidic surface functional groups such as carboxyl, phosphoryl and amino groups that are responsible for the reactivity of bacterial cells which is responsible for forming metal scavenging properties of bacteria $(\mathrm{Ku}-$ lczycki et al. 2002).

\section{Conclusion}

The use of different amendments has emerged as a viable and eco-friendly solution to remediate oil-sludge-contaminated soils/sites. The concoction of different additives such as Vetiver for rhizodegradation, bioaugmentation for enhanced microbial degradation, addition of nutrients for stimulation of indigenous and augmented consortium and addition of bulking to increase porosity and aeration helped to remove maximum oil and TPH from the contaminated soil very efficiently. Also results of lysimeter study infer that use of Vetiver and consortium was helpful in reducing the concentration of heavy metals such as lead and cadmium which otherwise could have polluted groundwater. In addition, the positive correlation between dehydrogenase activity and oil degradation indicates that degradation can be monitored by measuring the soil dehydrogenase activity. Concluding over the findings, MAPT is a better option than bioremediation alone for remediating oil sludge contaminated sites and to maintain the fertility of soil.

Acknowledgments The authors are thankful to Dr. S. R. Wate, Director, CSIR-NEERI, Nagpur, for his kind support and encouragement.

\section{References}

Abdulsalam S, Bugaje IM, Adefila SS, Ibrahim S (2011) Comparison of biostimulation and bioaugmentation for remediation of soil contaminated with spent motor oil. Int J Environ Sci Technol 8(1):187-194

Alvarez VM, Marques JM, Korenblum E, Seldin L (2011) Comparative bioremediation of crude oil-amended tropical soil 
microcosms by natural attenuation, bioaugmentation, or bioenrichment. Appl Environ Soil Sci. doi:10.1155/2011/156320

ASTM (2000) Standard test methods for moisture, ash, and organic matter of peat and other organic soils. Method D 2974-00. American Society for Testing and Materials, West Conshohocken

Bamforth SM, Singleton I (2005) Bioremediation of polycyclic aromatic hydrocarbons: current knowledge and future directions. J Chem Technol Biotechnol 80:723-736. doi:10.1002/jctb.1276

Beskoski VP, Gojgic GC, Milic J, Ilic M, Miletic S, Solevic T, Vrvic MM (2011) Ex situ bioremediation of a soil contaminated by mazut (heavy residual fuel oil) - A field experiment. Chemosphere 83:34-40

Brandt R, Merkl N, Schultze-Kraft R, Infante C, Broll G (2006) Potential of vetiver (Vetiveria zizanoides L. Nash) for phytoremediation of hydrocarbon contaminated soils in Venezuela. Int $\mathrm{J}$ Phytoremediation 8:273-284. doi:10.1080/15226510600992808

Casida IE, Kelvin JD, Sntora DL (1964) Soil dehydrogenase activity. Soil Sci 98:371-376

Chang Z, Richard WW (1998) Organic bulking agents for enhancing oil bioremediation in soil. Bioremediat J 1(3):173-180

Danh LT, Truong P, Mammucari R, Tran T, Foster N (2009) Vetiver grass, Vetiveria zizanioides: a choice plant for phytoremediation of heavy metals and organic wastes. Int $\mathrm{J}$ Phytoremediation 11(8):664-691. doi:10.1080/15226510902787302

Edema CU, Idu TE, Edema MO (2011) Remediation of soil contaminated with polycyclic aromatic hydrocarbons from crude oil. Afr J Biotechnol 10(7):1146-1149

Hooda V (2007) Phytoremediation of toxic metals from soil and waste water. J Environ Biol 28(2):367-376

Jackson ML (1973) Soil chemical analysis. Prentice Hall of India Pvt. Ltd., New Delhi

Jain PK, Gupta VK, Pathak H, Lowry M, Jaroli DP (2010) Characterization of $2 \mathrm{~T}$ engine oil degrading indigenous bacteria, isolated from high altitude (Mussoorie), India. World J Microbiol Biotechnol 26:1419-1426. doi:10.1007/s11274-010-0316-8

Juwarkar AA, Singh SK, Mudhoo A (2010) A comprehensive overview of elements in bioremediation. Rev Environ Sci Biotechnol 9:215-288. doi:10.1007/s11157-010-9215-6

Kathi S, Khan AB (2011) Phytoremediation approaches to PAH contaminated soil. Indian J Sci Technol 4(1):56-63

Kulczycki E, Ferris FG, Fortin D (2002) Impact of cell wall structure on the behavior of bacterial cells as sorbents of cadmium and lead. Geomicrobiol J 19(6):553-565. doi:10.1080/01490450290098586

Lasat MM (2000) Phytoextraction of metals from contaminated soil: a review of plant/soil/metal interaction and assessment of pertinent agronomic issues. J Hazard Subst Res 2:1-25

Li GH, Zhang X, Lu XX (2002) Biodegradation of residual petrochemicals and microbial activities in polluted soil. Earth Sci J China Univ Geosci 2:181-185
Mishra S, Jyot J, Kuhad R, Lal B (2001) In situ bioremediation potential of oily sludge-degrading bacterial consortium. Curr Microbiol 43:328-335. doi:10.1007/s002840010311

Mittal A, Singh P (2010) A feasibility study for assessment of In-situ bioremediation potential of a crude oil degrading Pseudomonas consortium. J Sci Res 2(1):127-137

Parrish ZD, Banks MK, Schwab AP (2005) Effect of root death and decay on dissipation of polycyclic aromatic hydrocarbons in the rhizosphere of yellow sweet clover and tall fescue. J Environ Qual 34:207-216

Pelletier ED, Delille D, Delille B (2004) Crude oil bioremediation in sub-Antarctic intertidal sediments: chemistry and toxicity of oiled residues. Mar Environ Res 57:311-327. doi:10.1016/j. marenvres.2003.07.001

Rhykerd RL, Crews B, McInnes KJ, Weaver RW (1999) Impact of bulking agents, forced aeration, and tillage on remediation of oilcontaminated soil. Bioresour Technol 67:279-285

Roldan A, Salinas JR, Garcia MM, Alguacil G, Diaz, Caravaca F (2004) Changes in soil microbial activity following conservation tillage practices in a sorghum field under subtropical conditions. 13th International soil conservation organisation conference-Brisbane. Conserving Soil and Water for Society: Sharing Solutions Paper No. 687 p 1

Salleh AB, Ghazhali FM, Rahman RNZA, Basri M (2003) Bioremediation of petroleum hydrocarbon pollution. Indian J Biotechnol 2:411-425

Shi S (2009) Influence of root exudates on soil microbial diversity and activity. PhD thesis, Lincoln University New Zealand

Tyagi M, Manuela M, Fonseca R, Carvalho CR (2011) Bioaugmentation and biostimulation strategies to improve the effectiveness of bioremediation processes. Biodegradation 22:231-241. doi:10.1007/s10532-010-9394-4

USEPA. Method 3540C (1996) Soxhelet extraction. United States Environmental protection agency, Washington, DC

Vasudevan N, Rajaram P (2001) Bioremediation of oil sludgecontaminated soil. Environ Int 26(5-6):409-411

Verma S, Bhargava R, Pruthi V (2006) Oily sludge degradation by bacteria from Ankleshwar, India. Int Biodeterior Biodegrad 57: 207-213. doi:10.1016/j.ibiod.2006.02.004

$\mathrm{Xu} \mathrm{Y,} \mathrm{Lu} \mathrm{M} \mathrm{(2010)} \mathrm{Bioremediation} \mathrm{of} \mathrm{crude} \mathrm{oil-contaminated} \mathrm{soil:}$ comparison of different biostimulation and bioaugmentation treatments. J Hazard Mater 183:395-401. doi:10.1016/j.jhazmat. 2010.07 .038

Zhang ZZ, Su SM, Luo YJ, Lu M (2009) Improvement of natural microbial remediation of petroleum-polluted soil using graminaceous plants. Water Sci Technol 59(5):1025-1034 